\title{
The Effectiveness of Inquiry-Based Module to Empower the Students' Critical Thinking Skills
}

\author{
$1^{\text {st }}$ Susilowati \\ Science Education, Postgraduate \\ Program, SebelasMaret University \\ (UNS) \\ Surakarta, Indonesia \\ corresponding author: \\ sadalisusilo@gmail.com
}

\author{
$2^{\text {nd }}$ Sajidan \\ Science Education, Postgraduate \\ Program, SebelasMaret University \\ (UNS) \\ Surakarta, Indonesia \\ sajidan@fkip.uns.ac.id
}

\author{
$3^{\text {rd }}$ Murni Ramli \\ Science Education, Postgraduate \\ Program, SebelasMaret University \\ (UNS) \\ Surakarta, Indonesia \\ mramlim@staff.uns.ac.id
}

\begin{abstract}
Critical thinking is one of the $4 \mathrm{C}$ skills of the $21^{\text {st }}$ century have to be mastered by students to analyze the phenomena of science and think for the well-being in the world. Some factors are argued as the key points to nurture the skill, such as the learning strategies, and the content of learning which should contextually and inquiry-based presented. The purpose of this study was to determine the effectiveness of the module which was designed based on the inquiry-lesson to improve the students' critical thinking skills. Subjects were selected from the biggest Madrasah Aliyah (Islamic High School) and credited as - A\| in Magetan District, East Java Province, Indonesia. This study was conducted in the academic year of 2016-2017. All eleventh-grade classes from the selected school were randomly selected to find out the two homogeneous classes for control and experiment class. A test for critical thinking was constructed based on the indicators by Facione. The independent t-test experiment resulted in the p-value of $0.000(p<0.05)$. The score gap between pre- and post-test was $31.93 \%$ in the experiment class, while, the control class was $16.66 \%$. Based on the results, it can be concluded that the inquiry-lesson-based module on human excretory system topics can effectively improve the students' critical thinking skills.
\end{abstract}

Keywords-Module; Inquiry-based learning; Critical thinking skills.

\section{INTRODUCTION}

The $21^{\text {st }}$ century is the era of international challenges and global competition in science and technology. Progress in science and technology are forcing the people to improve themselves to face the problem and to be open to innovations and changes [1]. One of the essential competencies in dealing with the $21^{\text {st }}$ century is the critical thinking skills. Critical thinking skills are the essential skills required to adapt with the competitions today and the future.

King states that high-level thinking skills are included in the critical thinking, logical thinking, reflective thinking, meta-cognition, and creative thinking [2]. Active learning that involves the students in learning processes which commonly contain these components and critical thinking skill is a skill that will bring students to be able to argue and facing the real problems critically.

Constructivist learning models promote a studentcentered learning model (Zaini, 2004). Considering the current facts, the teachers should change their rule from - to teach the students\| to -to make the students learn, $\|$ both concept (content) and the process of (scientific works) (Ridwan, 2010). Students have to understand the concept contextually by following some scientifically based works, such as doing a series of observations and experiment. The teacher should play a role to facilitate the students to learn by using a constructivist approach.

According to the standard of biology curriculum in Indonesia, the objectives of biology learning are; 1) to foster the students' scientific attitudes such as honest, objectivity, open- minded, tenacious, critical thinking, and cooperativeness; 2) to develop experiences for the students to propose and test hypotheses through experiments and communicate the experimental results. 3) to develop students' analytical, inductive, and deductive thinking skills (Permendiknas, 2006). To achieve those goals it also recommended to use the scientific approach, i.e., observing, asking, trying, associating, and communicating during the process of science learning. 
In reality, students' critical thinking skills in Indonesia is still far from expectations. The TIMMS's data showed the Indonesian students' ability in science and mathematics was ranked 40 of 42 countries (TIMMS, 2011). Assessment of the PISA in 2012 showed the average score of Indonesian students' scientific literacy was 382, far below the average international score (500) and put Indonesia ranked 63 out of 64 countries [3]. These facts showed that the Indonesian students' critical thinking abilities remain low. The research by Priatna showed that the critical thinking skill of junior high school students in Bandung, one of the big cities In Indonesia, was scored low [4]. The similar research by Winarti in Yogyakarta indicated that the skill of analyzing and reasoning of the Islamic high school students was also low.

The most effective way to develop critical thinking skills is to develop the learning process that incorporates the critical thinking training. Developing the critical thinking skills is a continuous process which should not only be done in the class, but should be implemented in the form of questions, and learning activities that focus on higher thinking levels (Reddington, 2012). Development of critical thinking is effective in the independent learning environment. Learning biology needs to be supported by textbooks that encourage the students to learn independently and guide the students to find concepts through the process of discovery.

Our preliminary study showed that students' critical thinking skills were still low with an average score of $47.41 \%$. The low score of student's critical thinking skills is might be influenced by learning approaches that have not provide the opportunities for students to improve their critical thinking skills. Results from the preliminary observation also showed the domination of teacher in the learning process.

Mapping analysis of the eight National Standards of Education at one IHS in Panekan, Magetan City, showed a gap in the standard of the process $(2.85 \%)$. The inadequate standard of the process showed that the teachers were still prioritizing the product aspects rather than the processes aspect of learning. The result of the analysis also showed the scores of Biology's Final Exams in the last four years were unstable there is $70.68 \%$ in 2012 , to $71.17 \%$ in 2013 , to $61.92 \%$ in 2014 and $58.98 \%$ in 2015 . The students' scores of the human excretion system also unstable with the score of 67.50 in 2012, to 82.19 in 2013, and to 62.24 in 2016. Based on those descriptions, there was a gap between ideal conditions and facts. Biology learning needs to be supported by teaching media and strategies that encourage students to find the scientific concepts independently.
The inquiry is the proper learning model to encourage the students to find concepts through independent discoveries, reflect their works, conclude, and generate the predictions. It also motivated the students to be more active in the learning process [3;4]. Lawson (2000) stated the inquiry-based biology learning curriculum to help the students to develop critical thinking skills and concepts mastery.

Carl J. Wenning introduced the six-level of inquiry learning approach in physics, ranging from basic to higher levels, are discovery learning, interactive demonstrations, inquiry lessons, inquiry labs (guided, bounded and free Inquiry), and hypothetical inquiry (pure and applied inquiry) [2]. The inquiry lesson model is oriented towards discovery-based.

Learning model, where if it is combined with the critical thinking training, it is argued to be able to improve the students' critical thinking skills. The syntax for the inquiry are; 1) observation; 2) manipulation; 3) generalization; 4) verification; and 5) application [2].

Student's critical thinking skills can be trained through constructivist-based learning models (Thompson, 2011). Constructivist learning can be done by providing the opportunities for the students to experimenting or inquiring (Vijayaratna, 2009). Critical thinking skills can be trained through inquiry learning models that suitable for the demands of the Indonesian Curriculum of 2013. Lawson (2000) stated that biology learning with the inquiry-based curriculum could develop the students' critical thinking skills and concepts mastery.

To improve the critical thinking skills of students, changing the learning model should be followed by the construction of content through a module, which is used by teacher and students. The module of the human excretory system is composed based on the approach of contextual learning and followed the steps of inquiry lessons as introduced by Carl $\mathrm{J}$. Wenning [2]. The inquiry lesson-based module was an independent teaching material designed to guide the students to find the principles of science and cooperative work to build their knowledge. The modules are expected to support the learning process, help the teachers to manage learning activities, and help the students to learn independently through structured activities to improve their critical thinking skills.

The present research aims to confirm the effectiveness of the draft module of the excretory system which was constructed based on the steps of the inquiry lesson, in improving the critical thinking skills of high school students. 


\section{METHODS}

The present research is the part of ten steps of the research and development modified from Borg and Gall (1983) on composing the inquiry lesson-based module of the human excretory system to improve the critical thinking skills of high school students. The ten steps are 1) research and information collecting, 2) planning, 3) development of the preliminary form product, 4) preliminary field testing, 5) main product revision, 6) central field testing, 7) operational product revision, 8) operational field testing, 9) final product revision, and 10) disseminate and implementation.

The operational field test was conducted to test the effectiveness of the module in the selected school. This research is a descriptive qualitative and quantitative research. The sample was selected by purposive random sampling at Islamic High School (IHS) in Magetan Regency by choosing public IHS which has the highest number of students and has been accredited A according to The National Education Standards Agency in Indonesia. The draft had been entirely developed in the prior research, and the present paper will cover the empirical validity of the drafted module. Quantitative research had been done to the purposively selected participants from Public IHS in Magetan.

\section{Participant}

The first step in selecting the sample was purposively choosing the IHS which has the most significant number of students and has been accredited A by the National Education Standardization Agency of Indonesia. The second step was to determinate the intake classroom, and since the excretory system will be taught in eleventh grade. All off eleventh-grade of science programs are 100 (one hundred) were selected. All classes were given the tests about critical thinking skills.

The tests' scores were undergone homogeneity and normality tests to verify whether the data were normal and homogeneously distributed. After that, two classes were randomly selected as experimental class and control class. All student in both classes agrees to join the research. The research subjects were 22 students, 16 female and six male of Science2 class as the experiment class, and 22 students, ten female and 12 female of Science-1 class as the control.

\section{Design}

Both classes were treated by pre-test and post-test on critical thinking skills developed by researchers based on the aspects of critical thinking indicators introduced by Facione [1]. The instruments had been previously tested for the validity and reliability. The experimental class was treated using inquiry modules aided lessons while the control class was moduleaidless lessons. The research was done by using an experiment control group pretest-post-test design (Table 1).

Table 1. The Research Design

\begin{tabular}{|c|c|c|c|}
\hline Experiment & $\mathrm{O}$ & $\mathrm{X}_{1}$ & $\mathrm{O}_{1}$ \\
\hline Control & $\mathrm{O}$ & $\mathrm{X}_{2}$ & $\mathrm{O}_{1}$ \\
\hline
\end{tabular}

$\mathrm{X} 1$ = Treatment (learning aided by the inquiry-lesson-based module).

$\mathrm{X} 2$ = Treatment (conventional learning usually based module).

$\mathrm{O}=$ Pre-test

$\mathrm{O}_{1}=$ Post-test

\section{Procedures}

The inquiry-lesson-based module was compiled through several consecutive steps. The first draft was validated by the content expert, module development expert, and pedagogical expert. The draft validation results were used as the consideration to develop the beta versions. The beta version was a pilot-tested to 12 students to know the students' responses and then validated by the education practitioners. The validation results were used as the consideration to develop the revised version. The revised version then validated by the assigned experts.

The validated module then used in the experimental class. The inquiry-lesson based module was incorporating the inquiry syntax with the critical thinking aspects from Fascione which includes interpretation, analysis, inference, evaluation, explanation, and self-regulation, and it was designed to encourage the students to learn independently to build their understanding.

The observation was integrated with aspects of interpretation, manipulation was integrated with aspects of analysis, generalization was integrated with aspects of inference, verification was integrated with aspects of evaluation, and the application was integrated with aspects of explanation and selfregulation. 
The module was developed based on the syntax of inquiry-lessons and integrated with the six aspects of critical think divided into three subtopics, i.e., the kidneys, the skin, and the liver and lungs.

\section{Data Collecting Instrument}

The critical thinking test developed by the researcher to assess the students' critical thinking skills. The test was compiled based on the critical thinking skill aspects from Facione [5]. The instrument was an objective questions test scored 1 , 2, 3 and 4 according to each criterion. The instrument validity was tested using Pearson Product Moment test with criteria if $\mathrm{r}_{\text {count }}>\mathrm{r}_{\text {table }}$ then the instrument was valid, and if $r$ count $<r$ table then the questions were declared as invalid and eliminated. Based on the validity test, the lowest score was 0.507 , and the highest score was 0.890 , higher than $\mathrm{f}$ table (0.396), which means the instrument was valid. While the reliability test by Cronbach's Alpha showed the score of $0.905>0.396$ which means each of the question itemswas reliable.

\section{Data Analysis}

The module's effectiveness was assessed using the normalized gain score (N-gain) from the pretest and post-test scores of both classes. The calculation for $\mathrm{N}$-gain was presented in Table 2.

If criteria for $\mathrm{N}$-Gain is $0<\mathrm{g}<0.3$ so the effectiveness of modules is low if criteria for $\mathrm{N}$-Gain is $0.3 \leq \mathrm{g} \leq 0.7$ so the effectiveness of modules is average and if criteria for $\mathrm{N}-$ Gain is $0.7<\mathrm{g}<1$ so the effectiveness of modules is high.

Table 2. Criteria for N-Gain Index and its Interpretation

\begin{tabular}{cc}
\hline $\mathbf{N}-$ Gain & Interpretation \\
\hline $0.7<\mathrm{g}<1$ & High \\
$0.3 \leq \mathrm{g} \leq 0.7$ & Average \\
$0<\mathrm{g}<0.3$ & Low \\
\hline
\end{tabular}

\section{RESULT AND DISCUSSIONS}

All students' in the experimental class are given pretest and posttest questions that measure critical thinking skills in the form of description concerning Likert scale. The students' pre- and post-test scores were tested for the normality and homogeneity to find out whether the data were normally distributed and homogeneous. Table 3 shows that the normality test for the experiments showed that the sig. The value was 0.417 for the pre-test and 0.214 for the post-test. The pretest sig. the value was $0.417>0.05$, so $\mathrm{H}_{0}$ was accepted, and the students' critical thinking skills test score in the pre-tests were declared as normally distributed. The post-test sig.value was 0.2412>0.05, so $\mathrm{H}_{0}$ was accepted, and the students' critical thinking skills test score was normally distributed. Based on the homogeneity test results showed that the homogeneity significance was 0.338 so $\mathrm{H}_{0}$ was accepted, and the data was declared as homogenous.

Table 3. The Results of the Normality and Homogeneity Tests

\begin{tabular}{cccc}
\hline Test & Result & Decision & Conclusion \\
\hline Normality & Sig 2-tailed pretest $=0.417$ & $\mathrm{H}_{0}$ Was accepted & Data were normal \\
Sig 2-tailed postest $=0.241$ & $\mathrm{H}_{0}$ Was accepted & Data were normal \\
Homogeneity & Sig=0.338 & $\mathrm{H}_{0}$ Was accepted & Data were homogenous \\
\hline The critical thinking aspect that is integrated & percentages for each aspect of experimental class \\
sith the syntax of the inquiry lesson consisted of six & test and post-test were shown in Fig. 1.
\end{tabular}




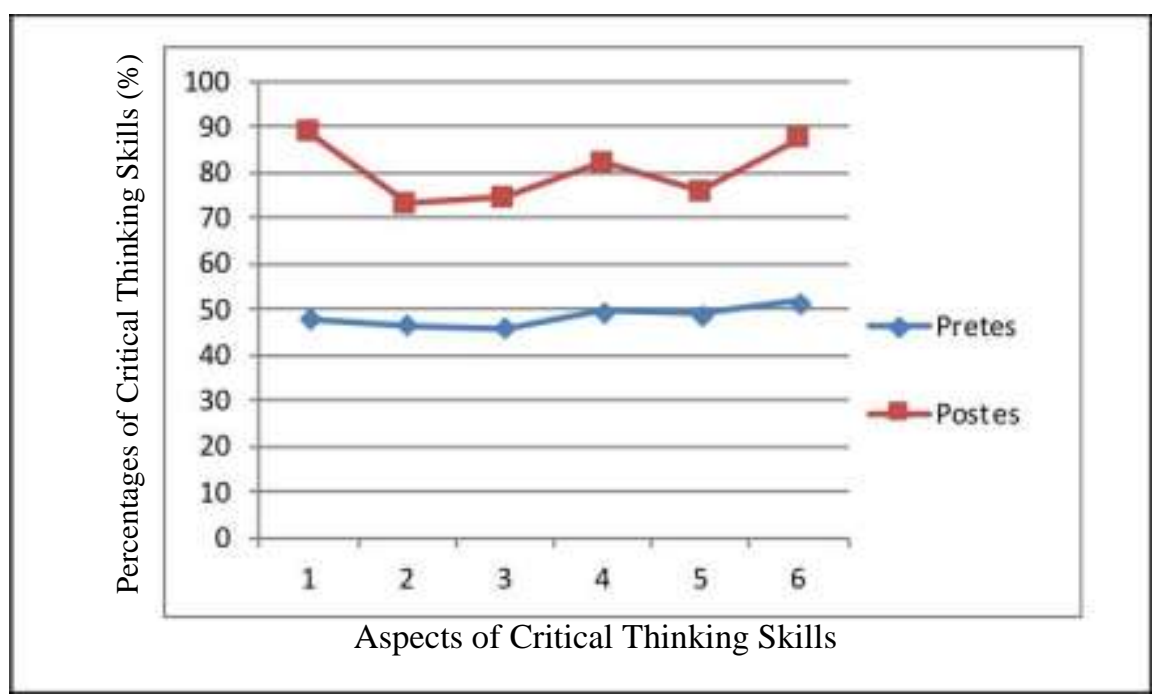

Fig. 1. Average Percentages of the Students' Critical Thinking Skills

1: Interpretation; 2: Analysis; 3: Inference; 4: Evaluation; 5: Explanation; 6: Self-Regulation

The percentages for each aspect of experimental class students' critical thinking skills mastery was $47.73 \%$ on the pre-test and $88.67 \%$ on the post-test. The analysis was $46.59 \%$ on the pre-test and $72.92 \%$ on the post-test. The inference was $45.83 \%$ on the pre-test and $74.50 \%$ on the post-test. The evaluation was $49.62 \%$ on the pre-test and $81.83 \%$ on the post-test. The explanation was $48.86 \%$ on the pre-test and $75.75 \%$ on the post-test. Moreover, the self-regulation was $51.52 \%$ on the pre-test and $87.08 \%$ on the post-test. The average pre-test score was $48.20 \%$, while the average post-test score was $80.13 \%$. Based on the pre-test and post-test scores, of the experimental class, found a score gap of $31.93 \%$. The descriptive analysis of pre- and posttest scores from both classes shown in Table 4.

Table 4. The Descriptive Analysis of Pre- and Post-test Scores from Both Classes.

\begin{tabular}{ccccccc}
\hline Tests & Class & Total & Mean & Std & Min & Max \\
\hline Pretest & Control & 22 & 46.63 & 6.97 & 32.50 & 67.50 \\
& Experiment & 22 & 48.20 & 6.34 & 42.50 & 67.50 \\
Averages & & & 47.50 & 6.65 & 32.50 & 67.50 \\
Post-test & Control & 22 & 60.07 & 5.61 & 32.78 & 77.50 \\
& Experiment & 22 & 80.12 & 6.38 & 60.09 & 90.00 \\
Averages & & & 70.10 & 5.99 & 46.44 & 83.75 \\
\hline
\end{tabular}

*Max score: 100

Table 4 showed the analysis of the students' critical thinking skills before and after the treatment of both classes. The control class's average pre-test score was 46.63; with the standard deviation of 10.00 ; the minimum value of 32.50 ; and the maximum value of 67.50. The average experiment class's pre-test score class was 48.20; with the standard deviation of 12.78 ; the minimum value of 31.67 and the maximum value of 67.50 . The control class's average post-test score was 60.07 ; with the standard deviation of 14.81 ; the minimum value of 32.78 and the maximum value of 77.50 . The experimental class's average post-test score was
80.12 ; with the standard deviation of 6.38 ; the minimum value of 60.09 and the maximum value of 90.00 .

The pre- and post-test score from both classes also tested using the paired sample t-test to assess the effectiveness of the learning with and without using the inquiry lesson module. The result of the paired sample t-test showed the correlation index of $0.475>$ 0.05 and sig. 2-tailed 0.00 as presented in Table 5. 
Table 5. The Results of the Paired Sample T-Test on the Experimental Class

\begin{tabular}{|c|c|c|c|}
\hline Test & Result & Decision & Conclusion \\
\hline Paired sample t-test & Sig 2-tailed $=000$ & $\begin{array}{r}\text { Sig } 2 \text { tailed }<0.05 \\
\mathrm{H}_{0} \text { was accepted. }\end{array}$ & $\begin{array}{c}\text { There was a difference } \\
\text { Between pre- and post- } \\
\text { test scores. }\end{array}$ \\
\hline
\end{tabular}

The n-gain calculation was used to find out how much the difference between pre-test and post-test score from both classes as shown in Fig. 2. Fig. 2. showed that the $\mathrm{N}$-gain of pre-and post-test scores of the experimental class was 0.62 (moderate), while the
$\mathrm{N}$-gain of pre- and post-test scores of control class was 0.25 (moderate). It means there were differences in the students' critical thinking skills in both classes, but the difference in the control class was smaller than the experimental class.

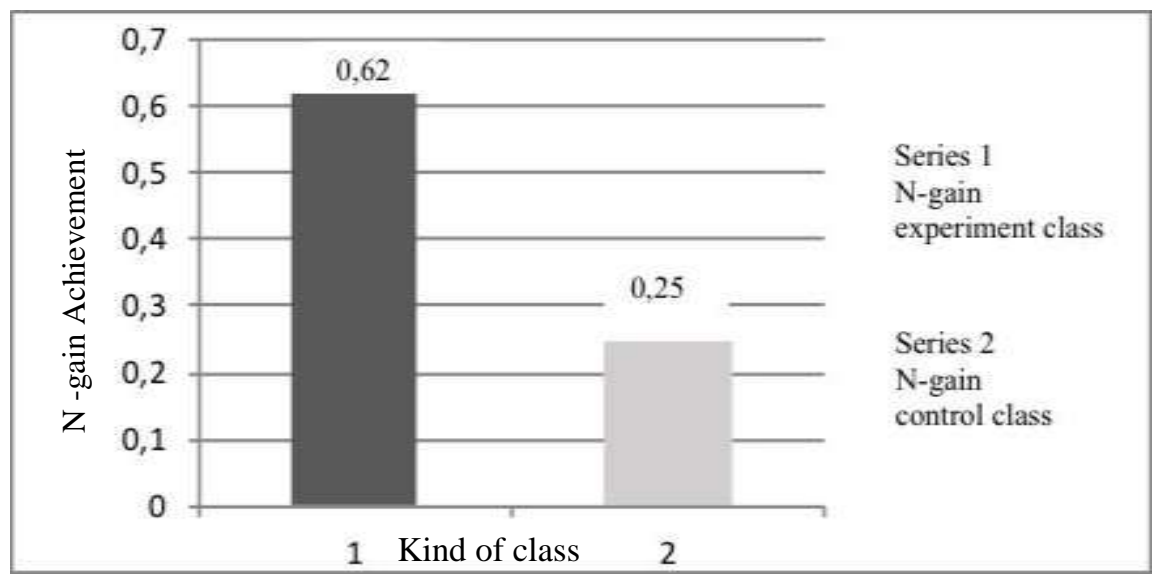

Fig. 2. N-gain from the Experimental and Control Class

\section{The Characteristics of the Inquiry-Lesson-Based Module}

The inquiry-lesson-based module is compiled based on the syntax of inquiry-lesson and integrated with the critical thinking aspects of the human excretion system topic. Inquiry lesson is one type of inquiry learning model [2]. In the inquiry lesson, teachers' guidance was gradually reduced, so the students making the inquiry independently, but the teacher provides guidance and questions to help the students in the learning process [2].

The inquiry-lesson module was developed based on the inquiry lesson syntax which includes:

1) Observation; the students observed the phenomena and involved in the learning process find the problems related to the phenomena. 2) Manipulation; the students find the factors that influence the phenomena and propose possible ideas for the investigation. 3) Generalization; the students make generalizations or conclusions based on their findings. 4) Verification; the students make predictions and do the investigation based on concepts from the earlier stage. 5) Application; the teacher provides encouragement and motivation to the students about their experiments [2].

The inquiry-lesson module was developed by integrating the inquiry lesson syntax with critical thinking aspects, so the students were involved in the process to find and build their conceptual understanding. Inquiry lesson helps the students to learn about the scientific concepts and understand the nature of science (Zion, 2007). It is relevant to the theory of constructivism, which involves the students to find and build their understanding (Suparno, 2013).

\section{The Effectiveness of the Inquiry-Lesson-Based Module}

The inquiry-lesson-based module can improve the students' critical thinking skills significantly. The module's effectiveness was evidenced by the improvement of the critical thinking skills $\mathrm{N}$-gain scores. Based on Figure 3, the average N-gain of the students' critical thinking skills in the experimental class was 0.62 (moderate) and higher than the N-gain of the control class $(0.25)$. The improvement of the $\mathrm{N}$-gain value of students' critical thinking skills 
resulted from learning aided by the inquiry-lessonbased module, thus help the students to improve their critical thinking skills. The module was presenting the scientific phenomena or real problems that exist in everyday life to help the students to find and build their conceptual knowledge through the process of discovery. Based on the result of the paired samples $\mathrm{t}$-test, got the probability (p) value of $0.003<0.05$ so the $\mathrm{H}_{0}$ was rejected, and there were differences in students' critical thinking skills before and after learning aided by the inquiry-lesson-based module. The inquiry learning involves the students in building the better understanding of biological concepts (Sanjaya, 2006). Group learning can also give the students opportunities to improve their cooperation and social interactions. Holmes (2013) concluded the inquiry allows the students to observe the objects or phenomena, ask the questions to gain knowledge, build the explanations based on natural phenomena, test their hypotheses, and exploring their ideas by communicating to other people. This discourse was following the aspects of critical thinking of interpretation, analysis, inference, evaluation, explanation, and self-regulation. It was relevant to Vygotsky's theory of learning, which states that higher mental functions arose from the conversation and cooperation between individuals.

The result of the data analysis showed that learning aided by the inquiry-lesson-based module could improve the students' critical thinking skill on the human excretion system topic. Trnova et al. (2012) concluded that inquiry-based learning was the proper method of learning science because it can motivate the students. Minner et al. (2009) state that the inquiry lesson was considered as the constructivist learning model because the students build their knowledge through the investigation of scientific phenomena. It explores the students' critical thinking skill because the students must make decisions through experiments and observations. Kumari (2013) stated the inquiry learning integrated with the module creates a more meaningful learning experience and can involve the students in the learning process. The inquiry lesson-based module contains learning activities that encourage the students to analyze and solve the problems based on the daily life facts. It relevant to Bruner's theory of learning that stated the independent learning activities by the learners can give more satisfying results.

\section{CONCLUSIONS}

Based on the result of the research, it can be concluded that the inquiry-lesson based module was effective to improve the students' critical thinking skills on the human excretion system, with the pvalue of $0.003(p<0.05)$. The results of statistical analysis showed the significant difference between the pre-test and post-test scores of the experimental class with the score gap of $31.93 \%$. While in the control class obtained the $\mathrm{p}$-value of $0.000(\mathrm{p}<0.05)$. The result of the paired samples t-test showed the difference between pre-test and post-test results in the control class with the score gap of $16.66 \%$ or lower than the experiment class.

\section{REFERENCES}

[1] Facione, P.A. Critical thinking: hat it is and Why it Count. http://www.insightassessment.com/content/download/1176/7 580/file/what\%26why2010.pdf, 2015.

[2] Wenning, C.J. 2007. A physics teacher candidate knowledge base. Journal of Physics Teacher Education Online, 4(3), Summer.2007 pp. 13-16.(Online)

[3] D. Islek \& C. Hursen. (2014). Evaluation of Critical Thinking Studies in Term of Content Analysis. Near East Universiy Department of Computer Education and Instructional Technology, Nicosia, Cyprus. Procedia Social and Behavioral Science .131. 29-299

[4] King FJ. Ludwik Goodson., Frank Rohani. Higher Order Thinking Skills (definition, Teaching Strategies Assesment).www.cala.fsu.edu. Retrieved on 20-08-2017.

[5] OECD. (2014) PISA 2012 Result in Focus: What 15-year-old know and what they can do with what they know. http://www.oecd.org/pisa/keyfindings/pisa-2012-resultoverview.pdf.

[6] Eren dan Serdar. 2013. Differences between Turkey and Finland based on Eight Latent Variables in PISA 2006. International Online Journal of Educational Sciences, 2013, 5 (1), 10-21.

[7] Ketpichainarong W., Panijpan B. \&Ruenwongsa, P. 2010. Enhanced learning of biotechnology students by an inquirybased cellulase laboratory. Intern. J. Environmental \& Science Education, 5, 169-187.

[8] Borg, W. R. Gall, M. D. \& Gall, J. P. (1983). Educational Research an Introduction. Boston: Allyn \& Bacon.

[9] Zion. 2007. The Spectrum of Dynamic Inquiry Teaching Practices. Research Science Education.37: 423-477. (Online).

[10] Suparno. Paul. 2013. Metodelogi Pembelajaran Fisika Kostruktivistik \& Menyenangkan. Yogyakarta: Universitas Sanata Dharma.h

[11] Bailin, S. (2002). Critical Thinking And Science Education. Science \& Education 11(4) 361-375. Netherlands: Kluwer Academic Publishers. Printed In the.

[12] Barak Miri., Ben-Chalm David., Zoller Uri. (2007). Purposely Reaching for the Promotion of Higher-Order Thinking Skills: A Case of Critical Thinking. E-Journal Res SciEduc 37:353-369. Springer Science +Business Media B.V

[13] BSNP. (2006). Panduan Penyusunan Kurikulum Tingkat Satuan Pendidikan Jenjang Pendidikan Dasar dan Menengah. Jakarta: Badan Standar Nasional Pendidikan.

[14] Campbell, N. R. (2008). Biologi. Jakarta: Erlangga.

[15] Daryanto. (2013). Menyusun Modul: Bahan Ajar Untuk Persiapan Guru Mengajar. Yogyakarta: Gava Media.

[16] Dogru Mustafa. 2008. - The Application of Problem Solving Method on Science Teacher Trainees on the Solution of the Environmental Problems. International Journal of Environmental \& Science Education, 3 (1), 9 - 18 ISSN 1306-3065.

[17] Fisher, A. (2014). Berpikir Kritis Sebuah Pengantar Terj. Erlangga.

[18] Gamaliel.,Septian, Airlanda\& S. Sudarisman. (2011) Festival sains dalam pembelajaran biologi Untuk meningkatkan keterampilan proses sains. Seminar Nasional VIII Pendidikan Biologi. FKIP: UNS

[19] Gulo W. (2004) Strategi Belajar Mengajar. Jakarta: Gramedia 
[20] Josef, T., Trnova, E., \&Sibor, J. 2012. Implementation of Inquiry-Based Science Education in Science Teacher Training. International Journal OnNew Trend In Education And Their Implication, 2, 199-209.

[21] Kemdikbud. (2013). Kurikulum 2013 Sekolah Menengah Atas(SMA)/ Madrasah Aliyah (MA.Jakrta: Kemdikbud.

[22] Kemdikbud. (2013). Pengembangan Kurikulum 2013. Paparan Kemendikbud dalam Sosialisasi Kurikulum 2013. Jakarta: Kemendikbud.

[23] Kumari, K. \&Kulshrestha, A. K. 2013. Impact of Constructivist Inquiry-Based Learning Approach on Science Achievement at Grade VIII. International Journal of Applied and Studies, 2, 1-5.

[24] Meika.,Suciati., Puguh karyanto.(2016.)Pengembangan Modul berbasis Inquiry lesson Untuk meningkatkan Dimensi Konten Pada Literasi sains Materi Sistem Pencernakan Makanan. Jurnal Inkuiry (2014). 05 (3). 090-103

[25] Minner, D. D., A. J. Levy, \& J. Century. 2009. Inquiry-based science instruction-What is it and does it matter. Results from a research synthesis Years 1984 to 2002. Journal of Research in Science Teaching, 1-24.

[26] Qiqi Yuiati Z. 2013. Implementasi pembelajaran Berbasis Kemampuan Otak (Brain based Learning) Untuk Meningkatkan Kemampuan Berpikir Kritis Siswa (studi Kuasi Eksperimen pada Siswa Sekolah dasar di Kota bandung). Universitas Pendidikan Indonesia, Bandung. http://repository.upi.edu./cgi/oai2accessedon 05-0802017.

[27] Quitadamo., Ian J., Celia L., Faiola., James E., Johnson \& Martha J., Kurtz. (2008). Community-based Inquiry Improves Critical Thinking in General Education Biology. CBE Life Science Education. 7(3), 327-337.

[28] Suprawoto, N.A. (2009). Mengembangkan Bahan Ajar dengan Menyusun Modul. https://www.scribd.com/doc/.../Mengembangkan-BahanAjar-dengan-Menyusun-Mod..accessedon5 Agustus2017.

[29] Toharudin, U, Hendrawati, S, dan Rustaman, A. (2011) Membangun Literasi Sains Peserta Didik. Bandung: Humaniora .

[30] Trianto.(2007). Model-Model Pembelajaran Inovatif Berorientasi Konstruktivistik: Konsep, Landasan Teoritis Praktis dan Implementasinya. Jakrta: Prestasi Pustaka Publisher.

[31] Trianto. 2010. Mendesain Model Pembelajaran Inovatif Progresif: Konsep, Landasan, dan Implementasinya pada Kurikulum Tingkat Satuan Pendidikan (KTSP). Jakarta: Kencana.

[32] _. 2010a. Levels of inquiry: Using inquiry sequences to teach science. Journal of Physics Teacher Education Online, 5(4), 11-19.

[33] _. 2010b. The Levels of Inquiry Model of Science Teaching. Journal of Physics Teacher Education. Online, 5(3), Winter2010.

[34] _. 2011. Sample learning sequences based on the Levels of Inquiry Model of Science Teaching. Journal of Physics Teacher Education Online. 6(2), Summer, pp. 17-30. 